\title{
RURAL EMPLOYMENT DIVERSIFICATION IN NORTH EAST INDIA: AN ANALYSIS
}

\begin{abstract}
Situational analysis of rural non-farm employment (RNFE) space in the North East India shows presence of severe regional variation. It also exhibits very high magnitude of feminisation and casualisation of employment in the construction sub-sector of RNFE. Although, the gendergap in the RNFE space in this region has virtually disappeared, gender deprivation is very much present and disquieting. This is reflected when women workers are increasingly pushed to undertake supportive, residual, casual and non-remunerative works vis-à-vis men workforce. Process analysis of structural transformation process of RNFE in north east region (NER) explains the role of both developmental as well as distress factors. The important identified developmental factors happen to be household income from agriculture, access to credit and distance from nearest urban centre. Poverty of households has emerged as one of the important distress factors pushing households to go in for non-farm activities as a strategy of survival. However, looking at the abrupt feminsation and casualisation aspects of women's employment during the period from 2004-05 to 2009-10, the distress factors seem to have acted heavy on the growth of RNFE in this region.
\end{abstract}

\section{Economic Development, Structural Transformation and Rural Non-Farm Employment}

Economic Development of any region can be understood, analysed and explained both as a situation and as a process. A situational explanation is basically based on the available data/information on important dimensions of economic development such as growth, employment, equity, investment, infrastructure, trade, etc. across time and space. This kind of explanation fundamentally provides an introduction of ideas and inklingsto subsequently go deep in analysis to the processes through which these explained developmental dimensions as outcomes manifest. Processes of economic development in general or leading dimensions of it in particular reflect on the

*Professor, Department of Economics, North Eastern Hill University, Shillong-793022, Meghalaya, Email: bhagirathi2@gmail.com.

This paper is based on the earlier work that the author had undertaken for a research project sanctioned by V.V. Giri National Labour Institute, Noida. The author gratefully acknowledges the assistance provided by the Institute.

Journal of Rural Development, Vol. 36, No. 2, April - June : 2017 
interplay of relevant factors/forces that cause these developmental dimensional outcomes (situations) to appear. Understanding and analysing economic development as a process for the North Eastern Region (NER) of India has been a comparatively difficult task because of various reasons such as non-availability of data/ quality data and the strong interlinkage between theinstitutional and economic factors. However, with the changing times, the need of the hour is to make the intervention strategy of various establishments of economic development such as government and community razor-sharp and effective. This to happen requires a broad understanding of the various subtle processes of economic development in the region.

Among various earlier theories developed to understand economic development as a situation and analyse its process in developing countries, the structural transformation theory stands out as a testament. Economists like Lewis (1955), Clark (1939), Fisher (1939) and Kuznets (1966) have analysed economic development in terms of structural transformation of economies. The essence of this theory and its various variants is that as economies grow, their income and employment structures undergo changes. These changes basically pertain to graduation of the economies from being dominated by agriculture (in terms of income and employment generation) to one experiencing increasing role for the industrial sector, declining role for the agricultural sector and finally a dominant role for the services sector.

In some of the prominent structural transformation theo ries cited above, structural transformation of the income and employment was explained in terms of a sustained shift from agriculture to industry and services sectors coterminous with a rural and urban dualistic framework. The Lewis theory in particular, identified the industrial sector with the urban space and the agricultural sector with the rural space. As a result of characterising the structural transformation situation in such spatial framework, the whole emphasis for creation of capital surplus through this process of structural transformation was laid with the urban sector. However, when the transfer of the so called surplus workers from the agricultural sector to the industrial sector gave rise to the urban informal sector along with its manifested problems of urban unemployment, underemployment and congestion; many of the developing countries tried to und o this process by bringing back the focus of development to rural areas. But the emphasis on rural development in the entirety of its approaches and strategieswas agriculture-centric. A situation and a process of emerging employment and income diversification within the rural space in the form of increased non-farm activities was being dubbed as'transitory' (Hymer and Resnick, 1969). The same was postulated to wither away with the consolidation of the forces of growth and development. Actual practice of development in the rural sector of the developing countries of the world during the last six decades and currently have not and don't exhibit such trends. On the contrary, the non-farm sector in these economies is fast growing and has started to provide jobs to almost 45 per cent of the rural workforce (Dirven, 2010).

Conventionally, all employments other than agriculture and itsallied activities are treated as non-farm. In the background paper for the World Development Report 1995, RNFSis defined as 'the sector which includes all economic activities in rural areas, except agriculture, livestock,fishing and hunting'. The most general convention is to include animal husbandry, 
hunting and trapping, forestryand logging, fishing, etc., in agriculture and accordingly, all other economic activities in rural areas would constitute RNFS (Chadha, 1993). In the Indian context, RNFE generally includes all rural employments in nonagricultural activities such as mining and quarrying, household and non-household manufacturing, processing, repairs, construction, trade and hotel, transport, storage, communications, and community as well as personal and other services in rural areas.

A brief review of studies undertaken at national and international levels, shows that the share of RNFE in total rural employment has substantially increased and correspondingly the share of rural farm employment has decreased (ILO 1984; Kauret et al,2010). Anotherinteresting dimension of the RNFE is its sectoral composition. Sectoral composition of RNFE provides insights into the nature of diversification and can also be linked to the factors responsible for causing this diversification. Studies undertaken by scholars across the developing world and in India do not find a uniform trend with regard to the share of different sectors within the non-farm sector.The share differs even within a country as a result of differing natural resource endowments, labour supply, location, infrastructural investments, culture, etc. Another kind of decomposition of RNFE is usually made based on gender ( $\mathrm{ha}$, 2006). This kind of decomposition and itsanalysis provides insights into how efficiently its female workforce is engaged in non-farm activities visa-vis the male workforce. This also throws light on the societal gender-based discrimination having itsimpact on activity and income space in the rural sector.

Finally, in the literature of rural non-farm economy, the most important part of the study of employment diversification is all about finding out the important factors that cause the observed diversification. Finding out these factors has a lot of policy importance.Generally, thesefactors are broadly classified into two categories, i.e., development (pull) and distress (push) factors. Predominance of each category of factors is having its obvious implications for the nature of economic development of that region. Many of the macro and household studies based on secondary and primary data have identified pull factors such as (i) agricultural growth (Mellor, 1976), (ii) urbanisation (Hazell and Haggblade, 1991; Srivastav and Dubey, 2002), (iii) literacy (Ranjan 2009), (iv) commercialisation of agriculture (Vaidyanathan, 1986), (v) infrastructure (World Bank, 1996; Jonasson and Helfand, 2010) to be responsible for the growth of RNFE. The important push factors that have been found to influence the growth of RNFE are declining land-man ratio and unemployment (Verma and Verma,1995; Vaidyanathan, 1986) and Poverty (Srivastav and Dubey, 2002).

\section{North Eastern Region, Structural Transformation and Rural Employment Diversification}

The NER in our study includes the seven States of Arunachal Pradesh, Assam, Meghalaya, Manipur, Mizoram, Nagaland and Tripura.Sikkim which is a late entrant into the political map of NER has been excluded from our study because of lack of comparative data for earlier periods. If the patterns of development in the NER are positioned in the structural transformation framework, it exhibits a kind of transformation wherein the agricultural sector's share to the region's domestic product has been declining and the share of services sector has been fast increasing. The share of the industrial sector has been increasing but very slowly (Panda, 2012). An important sub-dimensional manifestation of the structural transformation process is the 
transformation in employment or activity space. Understanding this situation and process is fundamental to have a complete understanding of the whole economic transformation process in this region.

The economy of NER is predominantly rural. Approximately 80 per cent of the area is rural in character. Over the last six decades, this region has undergone various socio-economic changes initiated and undertaken by different developmental establishments and led by the all powerful institutions of government. Because of significant improvementsin literacy and health, the Human Development Index (HDI) of the region currently stands higherthan the country's average. There has also been some expansion and improvements in many of the infrastructural provisions like housing, roads, power, etc. Along with these positive developments, some depressing developments have also come up naturally or otherwise. The land-man ratio has started deteriorating because of very high population growth. The capacity of agriculture to create more jobsis getting constrained because of modernisation and mechanisation. Presence of insurgency and rent-seeking behaviour in a number of States of the region do not attract private investment worth the name from outside. Against such a backdrop, the structural transformation in rural employment space exhibits a gradual shift of employment from the farm to the non-farm sector. During the period 1993-94 to 2009-10, the percentage of people engaged in rural non-farm sector has risen from 24.7 to 34.9 (Panda, 2012). As time passes and if some of the above-mentioned forces get strengthened, more and more people in the rural areas would get into the non-farm sector.These developments require a thorough study with regards to the trends, nature and factors responsible for the observed diversification of employment in the rural sector of NER. Such an analysis of the situation and process of diversification of employment would be very handy for the development establishments like the government, NGOs and communities to properly tailor their development related intervention strategies in the region. Mapping RNFE across sectors for the region as a whole and for the individual States can be considered crucial in the context of the region experiencing regional imbalance in development.

\section{Methodology}

Unlike major States of the country,studies on structural transformation and particularly employment diversification in rural areas of NER are not many. The central agencies like NSSO and Census of India collect data with regard to employment and activities but these data are available with a gap of five and ten years, respectively. Census authorities are yet to release economic activity-wise data for 2011 . We have therefore, used NSSO quinquennial data to find out the trends, growth and composition of RNFE in the NER. However, to understand the nature of RNFE and more particularly to explain the process of employment diversification by capturing the important factors responsible for its growth at the household level, we have collected primary data from 1000 households (hhs) spread over 10 villages and 5 districts in Assam and Meghalaya.The method of multi-stage sampling is used. In stage 1, five districts (three in Assam and two in Meghalaya) are selected purposely taking into consideration the geographical location and regional representation.

In stage II, from each of the districts two villages are selected purposely depending on 
their distance from the nearest urban centre. From each village, 100 households have been selected randomly from amongst the households residing in the village. In caseswhere the required number of households in any village is not available, the same isreplaced by the households in the other selected villages in the same district. In total, 1000 households (663 Non-farm and 337 Farm) are selected and surveyed. Details of the sample selection are given in Table 1.

Table 1: Details of Sample Selection

\begin{tabular}{|c|c|c|c|c|c|}
\hline State & District & Village & Farm & Non-farm & Total \\
\hline \multicolumn{6}{|c|}{ Meghalaya } \\
\hline \multirow[t]{2}{*}{1} & Jaintia hills & a. Ummulong & 53 & 47 & 100 \\
\hline & & b. Nongbah & 43 & 57 & 100 \\
\hline \multirow[t]{3}{*}{2} & Ribhoi & a. Byrnihat & 63 & 54 & 117 \\
\hline & & b. Lawbyrwa & 47 & 36 & 83 \\
\hline & Total of Meg & & 206 & 194 & 400 \\
\hline \multicolumn{6}{|c|}{ Assam } \\
\hline \multirow[t]{2}{*}{1} & Nagaon & a. Halowa & 30 & 70 & 100 \\
\hline & & b. Niz-Narikoli & 40 & 60 & 100 \\
\hline \multirow[t]{2}{*}{2} & Jorhat & a. TarajanGayan & 2 & 98 & 100 \\
\hline & & b. Azan Gaon & 13 & 87 & 100 \\
\hline \multirow[t]{4}{*}{3} & Kamrup & a. Beztula & 0 & 100 & 100 \\
\hline & & b. Nadia & 46 & 54 & 100 \\
\hline & Total of Assa & & 131 & 469 & 600 \\
\hline & Grand Total & & 337 & 663 & 1000 \\
\hline
\end{tabular}

Trends, Geographical Spread and Gender Facets of RNFE in North Eastern Region

Trends and Spread: As discussed earlier, classifying the employment space in the rural sector in the form of farm and non-farm employment providesabroad view of the trends and nature of its diversification. In most of the developing countries of the world including India, the share of RNFE has been increasing as against a decline in farm employment. Using NSSO usual status data (ps+ss) for industrial classification of activities collected in different rounds, we have estimated the broad trends in the share of RNFE over a period of 16 years from 1993-94 to 200910 and the same is produced in Table 2.

Table 2: Percentage Share of Rural Non-farm Employment in NER and India

\begin{tabular}{lcccc}
\hline NER/INDIA & \multicolumn{4}{c}{ Percentage Share } \\
\hline NER & $1993-94$ & $1999-00$ & $2004-05$ & $2009-10$ \\
INDIA & 24.7 & 25.2 & 26.1 & 34.9 \\
& 21.6 & 23.7 & 27.3 & 32.1 \\
\hline
\end{tabular}

Source: Author's calculation based on NSSO Reports of $50^{\text {th }}, 55^{\text {th }}, 61^{\text {st }}$ and $66^{\text {th }}$ rounds. 
Table 2 reveals that both in the countryas a whole and in the NER, there has been continuous diversification of employment in favour of non-farm sector. The percentage of peopleengaged in non-farm activities in NER has gradually increased from 24.7 in 1993-94 to 34.9 in 2009-10. During the same period,the country's average has increased from 21.6 per cent to 32.1 percent. It is therefore, obvious that the NER has undergone relatively higher employment diversification vis-à-vis the country.

Table 3: State-wise Share of Rural Non-farm Employment for Major States of the Country

\begin{tabular}{|c|c|c|c|}
\hline State & 50 Round (1993-94) & $61^{\text {st }}$ Round (2004-05) & $66^{\text {th }}$ Round $(2009-10)$ \\
\hline Andhra Pradesh & 22.7 & 28.3 & 31.3 \\
\hline Assam & 21.3 & 25.8 & 29.5 \\
\hline Bihar & 16.9 & 22.1 & 33.1 \\
\hline Chhattisgarh & 9.4 & 13.9 & 15.1 \\
\hline Gujarat & 20.7 & 22.8 & 21.7 \\
\hline Haryana & 28.6 & 36.0 & 40.2 \\
\hline Himachal Pradesh & 22.8 & 30.6 & 37.1 \\
\hline Jammu \& Kashmir & 28.0 & 36.2 & 40.3 \\
\hline Jharkhand & 23.9 & 30.1 & 45.2 \\
\hline Karnataka & 18.3 & 19.1 & 24.3 \\
\hline Kerala & 42.3 & 58.0 & 64.3 \\
\hline Madhya Pradesh & 13.8 & 17.5 & 17.6 \\
\hline Maharashtra & 20.3 & 20.1 & 20.6 \\
\hline Odisha & 21.9 & 31.0 & 32.4 \\
\hline Punjab & 22.7 & 33.2 & 38.2 \\
\hline Rajasthan & 19.2 & 27.2 & 36.7 \\
\hline Tamil Nadu & 31.3 & 34.7 & 36.3 \\
\hline Uttar Pradesh & 20.7 & 27.4 & 33.1 \\
\hline Uttarakhand & 34.9 & 21.8 & 30.5 \\
\hline West Bengal & 26.9 & 37.3 & 43.7 \\
\hline All-India & 21.7 & 27.4 & 32.1 \\
\hline
\end{tabular}

Source: Author's calculation based on NSSO Reports of $50^{\text {th }}, 55^{\text {th }}, 61^{\text {st }}$ and $66^{\text {th }}$ rounds.

Table 4: State-wise Share of Rural Non-farm Employment in NER

\begin{tabular}{lcccc}
\hline State/NSSO Rounds & $\begin{array}{c}50^{\text {th }} \text { Round } \\
(1993-94)\end{array}$ & $\begin{array}{c}55^{\text {th }} \text { Round } \\
(1999-00)\end{array}$ & $\begin{array}{c}61^{\text {st }} \text { Round } \\
(2004-05)\end{array}$ & $\begin{array}{c}66^{\text {th }} \text { Round } \\
(2009-10)\end{array}$ \\
\hline Arunachal Pradesh & 13.6 & 16.6 & 18.1 & 24.3 \\
Assam & 20.8 & 32.3 & 25.7 & 29.5 \\
Manipur & 36.2 & 24.7 & 30.7 & 46.6 \\
Meghalaya & 14 & 13.5 & 18.2 & 29.3 \\
Mizoram & 11.1 & 14.5 & 12.6 & 19.4 \\
Nagaland & 25.1 & 20.3 & 20.7 & 25.9 \\
Tripura & 52.4 & 54.3 & 56.8 & 69.4 \\
North-East & 24.7 & 25.2 & 26.1 & 35 \\
\hline
\end{tabular}

Source: Author's calculation based on NSSO Rep orts of $50^{\text {th }}, 55^{\text {th }}, 61^{\text {st }}$ and $66^{\text {th }}$ rounds. 
Studies in the context of the countryshow that there exist huge regional differences with respect to the incidence of RNFE (Unni, 1991; Pandey and Raman, 2012). For example, during 1993-93, 2004-05 and 2009-10, the State of Chhattisgarh had the lowest share of RNFE in total rural employment at 9.4, 13.9 and 15.1 percent, respectively and the State of Kerala had the highest share at 42.3, 58.0 and 64.3 per cent, respectively (Table 3). Regional variation is also observed in the context of the NER. Asit is evident from Table 4, in 1993-94 Tripura had the highest share of RNFE at 52.4 percent and Mizoram had the lowest share of RNFE at 11.1 percent. In 199900 ,Tripura again had the highest share of RNFE at 54.3 per cent and Meghalayahad the lowest share at 13.5 per cent. In 2009-10, Tripura continued to have the highest share of RNFE at 69.4 per cent and Mizoram like in the initial year of 1993-94 had the lowest share at 19.4 percent. Except for Tripura, Arunachal and Meghalaya, the trend in the share of RNFE for the other four States over the period from 1993-94 to 2009-10 has been erratic. When compared with the major States of the country (Table 3), this is typical of the RNFE situation of NER. In the context of 20 major States of the country, this kind of erratic trend is observed only with respect to one State i.e., Uttarakhand. In 1993-94, threeStates in NER viz., Tripura, Manipur and Nagaland had RNFE share higher than the region's average share. During the rest of the three subsequent NSSO rounds, only two States are having their RNFE shares higher than the region's average. Throughout the four periods of time, the number of States having RNFE share more than 30 per cent continued to remain at two only. Hence convergence in RNFE share is not happening in the region. One of the reasons for this may be the disproportionate increase in the share of RNFE fast for the States of Tripura and Manipur.Tripura's share of RNFE in 2009-10 has exceeded the share of Kerala at the level of the country.More on this is explained on the sectoral composition.

Table 5: Male-Female Employment in the Rural Non-farm Sector in NER and India

\begin{tabular}{llcccc}
\hline NER/INDIA & & \multicolumn{4}{c}{ Percentage Share of RNFE } \\
\hline \multirow{2}{*}{ NER } & Male/Female & $1993-94$ & $1999-00$ & $2004-05$ & $2009-10$ \\
& Male & 28.2 & 27.7 & 30.1 & 35.8 \\
& Female & 18.6 & 20.0 & 19.3 & 33.9 \\
& GenderGap (\% point) & 9.6 & 7.7 & 10.9 & 1.9 \\
& Male & 25.9 & 28.6 & 33.5 & 37.2 \\
& Female & 13.8 & 14.6 & 16.7 & 20.6 \\
& GenderGap (\% point) & 12.1 & 14.0 & 16.8 & 16.6 \\
\hline
\end{tabular}

Source: Author's calculation based on various census reports for 1991 and 2001 and NSSO reports of $50^{\text {th }}, 55^{\text {th }}, 61^{\text {st }}$ and $66^{\text {th }}$ rounds. 
Table 6: Share of Farm and Non-farm Employment Types in Total Female Employment by Region (Percentage)

\begin{tabular}{|c|c|c|c|c|c|c|c|c|c|c|c|c|c|c|}
\hline \multirow[t]{3}{*}{ Region } & \multicolumn{7}{|c|}{$\begin{array}{l}\text { Type of Employment Among } \\
\text { Female Workforce, 2009-10 }\end{array}$} & \multicolumn{7}{|c|}{$\begin{array}{l}\text { Percentage Change in Type of Employment } \\
\text { Among Female Workforce, 1983-84 to } \\
2009-10\end{array}$} \\
\hline & \multicolumn{2}{|c|}{$\mathrm{SE}$} & \multicolumn{2}{|c|}{ CFW } & \multirow[t]{2}{*}{$\mathrm{VE}$} & \multicolumn{2}{|c|}{ CE } & \multicolumn{2}{|c|}{$\mathrm{SE}$} & \multicolumn{2}{|c|}{ CFW } & \multirow[t]{2}{*}{ WE } & \multicolumn{2}{|c|}{ CE } \\
\hline & $\mathrm{F}$ & NF & $\mathrm{F}$ & $\mathrm{N}$ & & $\mathrm{F}$ & NF & $\mathrm{F}$ & NF & $\mathrm{F}$ & $\mathrm{NF}$ & & $\mathrm{F}$ & NF \\
\hline Vorth & 33.1 & 6.1 & 32.1 & 2.4 & 17.0 & 4.9 & 4.4 & -20.1 & 49.8 & -0.5 & 53.8 & 67.1 & 43.0 & 132.9 \\
\hline Centre & 13.7 & 4.7 & 41.6 & 3.2 & 5.5 & 21.4 & 9.8 & -36.0 & 29.9 & -9.7 & -19.0 & 45.8 & 16.0 & 272.7 \\
\hline Vorth-East & 12.1 & 7.3 & 39.6 & 3.2 & 14.2 & 12.0 & 11.6 & -59.5 & -32.8 & 95.5 & 125.9 & -27.0 & -8.6 & 133.4 \\
\hline East & 8.5 & 13.9 & 24.4 & 7.3 & 10.3 & 26.1 & 9.5 & -53.9 & 86.5 & 6.3 & 47.0 & 85.3 & -25.7 & 73.0 \\
\hline West & 7.7 & 7.3 & 30.3 & 3.1 & 12.7 & 34.2 & 4.7 & -52.7 & 82.2 & 4.7 & 9.7 & 101.6 & -7.8 & 4.1 \\
\hline South & 5.7 & 9.6 & 16.5 & 6.3 & 12.5 & 39 & 10.5 & -66.4 & 35.4 & -12.1 & 30.6 & 71.1 & 0.2 & 67.4 \\
\hline ndia & 10.7 & 8.0 & 29.0 & 4.6 & 10.5 & 28.4 & 8.8 & -46.5 & 44.4 & -2.9 & 14.5 & 70.3 & -5 . & 95.0 \\
\hline
\end{tabular}

Source: Author's modified presentation based on the work of Lahoti and Swaminathan, 2013.

Note:SE=Self-Employment, CFW=Contributory Family Workers, We=RegularWage/Salaried Employment, $\mathrm{CE}=$ Casual Employment, $\mathrm{F}=$ Farm Sector, $\mathrm{NF}=$ Non-farm Sector

Table 7: Share of Farm and Non-farm Employment Types in Total Male Employment by Region (Percentage)

\begin{tabular}{|c|c|c|c|c|c|c|c|c|c|c|c|c|c|c|}
\hline \multirow[t]{3}{*}{ Region } & \multicolumn{5}{|c|}{$\begin{array}{l}\text { Type of Employment Among } \\
\text { Male Workforce, 2009-10 }\end{array}$} & & \multicolumn{8}{|c|}{$\begin{array}{l}\text { Percentage Change in Type of Employment } \\
\text { Among Male Workforce, 1983-84 to 2009-10 }\end{array}$} \\
\hline & \multicolumn{2}{|c|}{ SE } & \multicolumn{2}{|c|}{ CFW } & \multirow[t]{2}{*}{ WE } & \multicolumn{2}{|c|}{$\mathrm{CE}$} & \multicolumn{2}{|c|}{ SE } & \multicolumn{2}{|c|}{ CFW } & \multirow[t]{2}{*}{ WE } & \multicolumn{2}{|c|}{ CE } \\
\hline & - & $\mathrm{N}$ & - & NF & & $F$ & 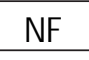 & & 1 & 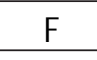 & $\mathrm{NF}$ & & $F$ & $\mathrm{NF}$ \\
\hline & & & & 3.0 & 9 & 5.9 & 13.2 & & 28.9 & 11 & & 7.7 & & \\
\hline nt & & & & & & & 15.2 & & & 0 & & .4 & & \\
\hline rth & 3 & & & & 17.0 & 8.3 & 9.5 & -24.3 & & 240.1 & 91.4 & -22.6 & & \\
\hline st & 0.9 & .4 & 4.5 & 1.8 & 12.4 & 24.2 & 12.8 & -2 & 6 & 8.0 & 4.8 & -33.0 & ) & 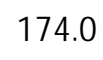 \\
\hline & & & $\ulcorner 0$ & & 29.2 & & 9.2 & & 27.6 & 29.7 & & -0.7 & & \\
\hline uth & 13.5 & .9 & 3.1 & 1.6 & 22.8 & 22.8 & 16.2 & -4 & 17.4 & 0.2 & 5.0 & 6.2 & -10.5 & \\
\hline dia & 20.9 & 20.6 & 5.5 & 2.0 & 19.7 & 17.7 & 13.6 & -33.1 & 29.5 & 13.6 & 74.8 & -6.2 & -11.5 & 5131.0 \\
\hline
\end{tabular}

Source: Author's modified presentation based on the work of Lahoti and Swaminathan, 2013.

Note: $\mathrm{SE}=$ Self Employment, CFW=Contributory Family Workers, We=Regular Wage/Salaried Employment, $\mathrm{CE}=$ Casual Employment, $\mathrm{F}=$ Farm Sector, NF= Non-farm Sector.

Gender Facets of RNFE in NER : One of the important means of understanding the structural transformation process in the rural employment space in developing societiesisdissecting of such employment with respect to gender. This dissection and its further probing in the event of existence of gender disparity can provide better understanding of the productivity of peopleand sectors in an economy. As seen from Table 5,all through the four NSSO rounds, the gender gap 
(calculated as the differences in the percentage shares of RNFE for both the genders at a given year/round) in NER has gradually decreased and has been much lower than the country as a whole. At the national level this gap has been continuously increasing. A striking feature of NER is that this gap suddenly over the period 200405 to 2009-10 has reduced to 1.9 percentage points from a high of 10.9 percentage points. One of the reasons for this may be the significant increase and growth in female employment in the construction sector of RNFE resulting in a situation that could be termed as feminisation of employment in construction sector of RNFE in NER. Table 9 shows that during this period of five years, female employment in the construction sector of RNFE in NER has increased from 7.8 to 47.7 per cent, a phenomenal increase of almost 40 percentage points. For the country as a whole this has increased by 18.7 percentage points.

In terms of annual growth rate over the period 1993-93 to 2009-10, construction sector employment for the females in NER has experienced the highest growth rate of $18.2 \mathrm{per}$ cent as against the national annual growth rate of 11.6 percent. Employment through MGNREGA could be one of the important factors for such a startling rise in female employment in construction segment of RNFE. As the employment created through MGNREGA is casual in nature, this also means that the construction sector has experienced increased casualisation of female employment. Lahoti and Swaminathan's findings (Table 6 and Table 7) add further credence to the above interpretation. They find a positive 133.4 per cent increase in female casual employment in non-agricultural employment in NER over the period 1983-84 to 2009-10 against 84.5 per cent for males. This magnitude of increase for the women workforce is the second highest among sixregionsfor which the data are presented. Further, for the year 2009-10, the percentage of female casual employment in NER was highest at 11.6 among all these six regions. For the males in the region it was 9.5 , the second lowest in the country. It is also observed that during the period 1983-84 to 2009-10, female employment under selfemployment category both in farm and non-farm sectors has undergone high negative per cent falls ( -59.5 and -32.8 , respectively), whereas female employment under contributing family work both in farm and non-farm sectors has experienced highest positive per cent rise (95.5 and 125.9 , respectively) among all the six regions. For the male workforce, employment under selfemployment category in the farm sector has undergone a much less per cent decrease (-24.3) and under non-farm sector highest increase of 56 per cent.

This trend is indicative of a situation of distress push and helplessness for the women workforce. Again, NER is the only region where during the period under discussion female employment in the regular wage/salary category has experienced a negative per cent fall. The implications of a significant per cent rise in contributing family women workforce in farm and non-farm sectors and a fall in the regular wage/salary employment category is that the distress factors are more at play when it comes to women's employment diversification in NER vis-a-vis the other regions of the country. It can also be reasoned out from these developments that although the gender gap in the region in non-farm employment space has almost disappeared, the gender bias or deprivation is very much present and worrying. Thisgender bias or deprivation is reflected when increased percentage of women workforce is pushed to undertake supportive, residual, casual and 
non-remunerative works vis-à-vismale workforce in the region.

\section{Composition of RNFE in NER}

Composition of RNFE (for all persons) : RNFE space is heterogeneous. As mentioned earlier under section 1.1, it includes in itsambit anumber of sub-sectors. A careful dissection of it over a reasonable long period of time provides valuable insights with respect to the nature of diversification and growth in employmentin the rural sector of an economy/region. It can also provide, if analysed properly,the different stages of development of an economy. The situation of composition of RNFE in NERand its comparison with the countryasa whole is presented in Table 8.

Table 8: Composition of RNFE in North East and India As Per Usual Status (PS+SS) by Broad Industry Division (Percentage): Persons

\begin{tabular}{|c|c|c|c|c|c|c|c|c|c|c|}
\hline \multirow[t]{3}{*}{ Industrial Category } & \multirow{2}{*}{\multicolumn{4}{|c|}{ NER }} & \multirow{2}{*}{\multicolumn{4}{|c|}{ India }} & \multicolumn{2}{|c|}{ Growth Rate } \\
\hline & & & & & & & & & NER & India \\
\hline & $\begin{array}{c}1993- \\
94\end{array}$ & $\begin{array}{c}1999- \\
00\end{array}$ & $\begin{array}{l}2004- \\
05\end{array}$ & $\begin{array}{c}2009- \\
10\end{array}$ & $\begin{array}{c}1993- \\
94\end{array}$ & $\begin{array}{l}1999- \\
00\end{array}$ & $\begin{array}{c}2004- \\
05\end{array}$ & $\begin{array}{c}2009- \\
10\end{array}$ & & \\
\hline Mining \& quarrying & 0.8 & 1.1 & 1.1 & 2.0 & 2.8 & 2.1 & 1.8 & 1.9 & 8.14 & 0 \\
\hline Manufacturing & 13.9 & 11.5 & 13.0 & 10.0 & 32.4 & 31.1 & 29.7 & 22.4 & 0.18 & 0.17 \\
\hline Electricity, water, etc. & 1.2 & 0.8 & 1.1 & 0.6 & 0.9 & 0.8 & 0.7 & 0.6 & -2.5 & 0 \\
\hline Construction & 10.2 & 10.7 & 14.1 & 31.3 & 11.1 & 13.9 & 17.9 & 29.3 & 9.7 & 8.9 \\
\hline $\begin{array}{l}\text { Trade, hotel and } \\
\text { restaurant }\end{array}$ & 18.8 & 19.4 & 23.4 & 21.3 & 19.9 & 21.4 & 22.3 & 19.9 & 3.1 & 2.51 \\
\hline $\begin{array}{l}\text { Transport, } \\
\text { storage and } \\
\text { communication }\end{array}$ & 5.3 & 5.1 & 6.6 & 6.6 & 6.5 & 8.8 & 9.2 & 9.1 & 3.63 & 4.65 \\
\hline $\begin{array}{l}\text { in. inter, business } \\
\text { act, etc. }\end{array}$ & 0.8 & 0.8 & 0.8 & 1.1 & 1.4 & 1.3 & 1.8 & 1.9 & 4.42 & 4.42 \\
\hline $\begin{array}{l}\text { Public admn., } \\
\text { education, } \\
\text { community } \\
\text { service etc. }\end{array}$ & 49.0 & 50.6 & 39.9 & 27.1 & 25.0 & 20.6 & 16.6 & 14.9 & -1.44 & -0.73 \\
\hline
\end{tabular}

Source: Author's calculation based on NSSO Reports of $50^{\text {th }}, 55^{\text {th }}, 61^{\text {st }}$, and $66^{\text {th }}$ rounds.

Table 8 reveals very interesting trends. In NER up to 2004-05, public services sector continued to remain the dominant employment type in non-farm category. It went on to account for half of the RNFE employment share up to 1999-2000. In 2004-05, its share gradually declined to 40 percent. At the national level, up to 2004-05, manufacturing sector continued to dominate the RNFE space with a little less than one-third share of the total employment. In 200910 , a great transformation-cum-convergence happened with respect to NER and the country in RNFE space. The construction sector emerged as the leading sector of employment with more or less similar share (approximately 30 per cent) in RNFE category both at the level of NER and the country. The implications of such a revealing development leading to convergence in 
construction sectoremployment may be because of a secular fall in public employment in NER because of the restructuring of public salaried/ regular employment and deceleration in manufacturing employment at national level because of technology-enabled manufacturing growth in large scale industries. Even with diminishing manufacturing employment at the level of the country, its share in RNFE in 2009-10 remains twice of such share for the NER. In fact NER's share of manufacturing employment in RNFE category has undergone a gradual decline during the whole period of 1993-94 to 2009-10. The other sector in RNFE category where there is more or less a convergence of employment share both at the NER and the country is trade, hotel and restaurant. Where the NER strikes a difference from the country is in the public services sector. Here even in 2009-10, the share of this sector in RNFEcategory in NER constitutes 27.1 per cent as against all India share of 14.9 per cent suggesting thereby that the dominance of the government as provider of employment in
RNFE domain, although has relatively decreased, still continues to be critical. This assumesfurther credence with the other important revelation that much of the employment creation in construction sector could be due to employment in public works programmes like MGNREGA. What finally we can read from these data is that RNFE in NER as a whole is yet to emerge as an autonomous productive form of employment, with exceptions of employment in sectors like trade, hotel and restaurant.

\section{Composition of Male-Female Work Participation}

in RNFE : Breaking down the sectoral space of RNFEwith gender Table 9presentsuswith intuitive findings. The males continue to be employed dominantly in publicadministration, education and community service (services sector) all through the period 1993-94 to 2009-10. Female employment was also predominant in the same sector up to 2004-05. However, in 2009-10, female employment in this sector plunged to 17.1 per cent. It experienced a massive 40 percentage point rise in the construction sector. Another

Table 9: Composition of RNFE in North East and India As Per Usual Status (PS+SS) by Broad Industry Division (Percentage): Males and Females

\begin{tabular}{llccccccccccc}
\hline Industrial Categories & \multicolumn{1}{c}{ NER } & \multicolumn{4}{c}{ India } & \multicolumn{3}{r}{ Growth Rate } \\
\hline & & \multicolumn{1}{c}{1993} & $1999-$ & 2004 & $2009-$ & 1993 & $1999-$ & $2004-$ & $2009-$ & NER & India \\
& & 94 & 00 & 05 & 10 & 94 & 00 & 05 & 10 & \\
\hline Mining \& & Male & 1.0 & 1.0 & 1.3 & 2.8 & 2.7 & 2.1 & 1.8 & 2.2 & 7.8 & 0.83 \\
Quarrying & Female & 1.6 & 1.5 & 0.5 & 0.6 & 2.8 & 2.1 & 1.8 & 1.5 & -2.5 & -1.78 \\
Manufacturing & Male & 9.6 & 7.1 & 7.7 & 7.6 & 27.1 & 25.4 & 23.6 & 18.9 & 0 & 0 \\
& Female & 35.3 & 27.0 & 29.0 & 16.6 & 49.6 & 50.7 & 50.2 & 36.4 & -1.02 & 0.43 \\
Electricity, & Male & 0.7 & 0.7 & 1.7 & 0.8 & 1.2 & 0.7 & 0.6 & 0.5 & 2.56 & -2.5 \\
water, etc. & Female & 0.5 & 0.0 & 0.0 & 0.0 & 0.7 & 0 & 0 & 0 & -100 & -100 \\
Construction & Male & 11.0 & 12.5 & 15.7 & 25.2 & 12.3 & 15.7 & 20.2 & 30.4 & 6.88 & 8.2 \\
& Female & 5.9 & 4.5 & 7.8 & 47.7 & 6.5 & 7.5 & 8.9 & 25.2 & 18.2 & 11.6 \\
Trade, hotel and & Male & 20.6 & 17.9 & 22.0 & 21.6 & 21.2 & 23.7 & 24.8 & 22.2 & 1.78 & 2.52 \\
restaurant & Female & 14.5 & 15.5 & 20.2 & 18.0 & 15.1 & 13.7 & 14.8 & 13.7 & 5.22 & 1.81 \\
\hline & & & & & & & & & & (Contd........)
\end{tabular}

Journal of Rural Development, Vol. 36, No. 2, April - June : 2017 
Table 9 (Contd.....)

\begin{tabular}{|c|c|c|c|c|c|c|c|c|c|c|c|}
\hline \multicolumn{2}{|c|}{ Industrial Categories } & & \multicolumn{4}{|c|}{ NER } & \multicolumn{2}{|r|}{ India } & \multicolumn{3}{|c|}{ Growth Rate } \\
\hline & & 1993- & 1999- & 2004 & 2009- & 1993- & 1999 & 2004- & 2009 & NER & ndia \\
\hline & & 94 & 00 & 05 & 10 & 94 & 00 & 05 & 10 & & \\
\hline Transport, & Male & 6.4 & 6.5 & 8.3 & 9.0 & 8.5 & 11.2 & 11.3 & 11.0 & 3.66 & 3.96 \\
\hline $\begin{array}{l}\text { storage and } \\
\text { communication }\end{array}$ & Female & 1.0 & 0.5 & 0.5 & 0.0 & 0.7 & 0.7 & 1.1 & 0.9 & -100 & 4.42 \\
\hline Fin. inter, & Male & 1.5 & 0.7 & 1.0 & 1.1 & 1.5 & 1.7 & 2.1 & 1.9 & 0 & 3.55 \\
\hline business, etc. & Female & 0.5 & 0.5 & 0.5 & 0.0 & 0.7 & 0.7 & 0.6 & 0.9 & -100 & 4.42 \\
\hline Public admn., & Male & 49.2 & 53.6 & 42.3 & 31.9 & 25.5 & 19.5 & 15.6 & 12.9 & -1.23 & -1.97 \\
\hline $\begin{array}{l}\text { education, } \\
\text { community } \\
\text { service, etc. }\end{array}$ & Female & 40.7 & 50.5 & 41.5 & 17.1 & 23.9 & 24.6 & 22.6 & 21.4 & -1.67 & 2.01 \\
\hline
\end{tabular}

Source: Author's calculation based on NSSO Reports of $50^{\text {th }}, 55^{\text {th }}, 61^{\text {st }}$, and $66^{\text {th }}$ rounds.

revealing trend seen with respect to female employment in RNFE is that excluding the construction and trade and hotel sectors, theother six sectors have witnessed negative annual growth during the period 1993-94 to 2009-10. Female RNFE is seen to be more concentrated in three of the sectors of RNFEi.e., construction, trade, hotelsand restaurantsand services, whereasmale employment is relatively more varied.

\section{Determinants of Participation of Households in Non-farm Activities}

As pointed out above, researchers have basically identified two sets of factorsi.e., pull and push factors being responsible for the growth of RNFE. In the context of NER, Panda (1999) and
Mishra (2007)have identified pull orpush and both pull as well as push factors being responsible for the growth of RNFE. Panda in the context of Arunachal Pradesh found agricultural growth to be positively and significantly correlated with percentage share of RNFE in 1991 and suggested that this relationship could be working through consumption and production linkages. However, hecould not test for the distress variables because of data constraints. Mishra too using field data for 288 households in the context of Arunachal Pradesh found education of the head of the household, ST status, size of operational holding and distance of the household from the nearest urban locality to beimportant factors determining household's entry to RNFE.

Table 10: Determinants of Participation of Households in Non-farm Activity: Binary Logistic Regression Results

\begin{tabular}{lccc}
\hline Variable & B & SE & WALD \\
\hline EDUHEAD & .036 & .040 & .777 \\
HHSIZ & .102 & .061 & 2.826 \\
HHIAL & $.000 *$ & .000 & 187.511 \\
LDOWN & -.034 & .032 & 1.125 \\
\hline
\end{tabular}

Journal of Rural Development, Vol. 36, No. 2, April - June : 2017 
Table 10 (Contd.....)

\begin{tabular}{lccc}
\hline Variable & B & SE & WALD \\
\hline ACCRDT_D & $1.329^{*}$ & .450 & 8.708 \\
HHPOV & $2.297^{*}$ & .388 & 34.975 \\
DISTNUC & $-.049^{*}$ & .013 & 13.787 \\
Constant & $2.595^{*}$ & .568 & 20.862 \\
$\mathrm{~N}$ & 1000 & & \\
-2 Log liklihood & 407.555 & & \\
Cox\&Snell R Square & .581 & & \\
NagelkerkeR Square & .806 & & \\
\hline
\end{tabular}

* Significant at 1 per cent level.

In this paper, we have also made an attempt to analyse the factors governing households' probability of participation in nonfarm employment in terms of a binary logit model. Based on the collected data from 1000 households, these factors have been grouped in to pull (developmental) and push (distress) categories. The important pull factors incorporated in the analysisare urban proximity, agricultural growth, accessto creditand education of the head of the household.Similarly,household poverty and land ownership have been included in the analysis as two important push factors. Household poverty is based on household income classtypes, which is included to suggest if households diversify into non-farm employment because of low incomeand distress. Households having an annual gross income of $₹ 30000$ or less have been classified as living below poverty. This has been done as per the practice being followed by the government of Assam and Meghalaya.The variable details are given below. The results of the model have been presented in Table 10.

(a) Dependent Variable i.e. engagement in primaryoccupation $(\mathrm{PO}): \mathrm{PO}=1$, if engaged in non-farm, otherwise 0 (b) Independent Variables:

1. EDUHEAD = Education of the Head of Household measured in terms of number of years of schooling.

2. HHSIZ=Size of the Household in terms of members

3. HHIAL=Household Annual Income from Agriculture (proxy foragricultural growth)

4. LDOWN=Land Owned by the household

5. ACCRDT_D $=$ Access to Credit Dummy, $=1$, if the household has access to credit; $=0$, otherwise.

6. HHPOV=Household Poverty Dummy, $=1$ if the household is a BPL Household; $=0$, otherwise i.e., if APL Household.

7. DISTNUC $=$ Distance of the Household from the Nearest Urban Centre, measured in terms of $\mathrm{km}$.

The predicative value of the model is reasonably good. Both the Cox \&Snell as well as Nagelkerke R square values are high. From the model it is obvious that participation of the households in non-farm activity is significantly influenced by household income from 
agriculture, access to credit, household poverty and distance from nearest urban centre. Increased income from agriculture (agricultural growth) might have positively influenced the growth of RNFE primarily through consumption linkages.This analysisgains credence when seen with the classification of the principal activity profile of the sample households (Table 11).

Table 11: Classification of Sample Households by Principal Activity

\begin{tabular}{lc}
\hline Activity Type & Percent Share \\
\hline Cultivator & 29.5 \\
Agricultural labour & 4.3 \\
Manufacturing & 1.3 \\
Construction & 8.1 \\
Trade and commerce & 25.7 \\
Transport & 3.2 \\
Servicesincluding govt. services and repairing activities & 27.9 \\
All occupations & 100
\end{tabular}

Source: Field Data.

From Table 11 , it is evident that about 26 per cent of the households are engaged in trade and commerce as their principal activity. These non-farm activities do not enhance directly the productive capacity of the rural economy. They basically represent the increasing consumption status of the rural households. Increase in the share of manufacturing and high-end services activities directly represents expansion in productive capacity (production linkage of agricultural growth) of the village economy.Share of manufacturing activity remains at 1.3 per cent only. Similarly, repairing, personal services and government services (services category) do not also reflect any significant expansion in productive capacity of the rural economy. All these point to a situation of employment diversification that most likely has happened through consumption linkages of agricultural growth. The agricultural growth-led production linkage diversification in NER seems to be weak. The other two development variables i.e., urban proximity and access to credit are also found to affect RNFE growth significantly. As usual, the positive significant value of ACCRDT_D coefficient implies that households that have access to credit have experienced increased diversification of non-farm activities. Urban proximity variable DISTNUC has a negative but statistically significant value. This suggests that nearer a household is to the urban centre; $g$ reater is the probability of its participation in non-farm activities. Education of the head of household and household size although are positively related to RNFE expansion, the value of their coefficients are not statistically significant. The implication of education coefficient not being found statistically significant could be that much of the employment expansion in RNFE in the study area was not high-end non-farm activities.

When it comes to distress or push factors, the household's probability of participating in RNFE is found to be positive and statistically significant with the household's poverty status. This eminently suggests presence of distress 
diversification of rural employment in the study area. Thus, we find the growth of RNFE and for that matter thestructural transformation process of employment space in NER to be result of both development as well as distress factors. Hence, both John Mellore's and Vaidyanthan's hypotheses of farm and non-farm linkage and distress diversification, respectively hold good when it comes to structural transformation of employment scenario in rural NER.

\section{Conclusion}

The employment situation in the rural sector in North Eastern Region of India has undergone visible transformation during the period 1993-94 to 2009-10. During this period, the share of non-farm employment has continuously increased and the share of farm employment has continuously decreased. As it stands in 2009-10, the share of RNFE in NER is relatively more vis-à-vis the country.A situational analysis of the trendsin RNFEshowsthe presence of severe regional variation in its space. It also shows the erratic nature of its growth vis-à-vis the country. When at the national level with respect to major States, some kind of convergence is visible on the share of RNFE, the NER exhibits no such tendency of convergence. This is basically because of States like Tripura and Manipur experiencing very high share of RNFE and the other States not being able to catch up with them. Dissecting RNFE space in NER with respect to gender reveals that during the period 1983-84 to 2009-10, female employment under self-employment category both in farm and nonfarm sectors has undergone high negative per cent falls, whereas female employment under contributing family work both in farm and nonfarm sectors has experienced highest positive per cent rise among all the six regions of the country. Again, NER is the only region where during the period under discussion, female employment in the regular wage/salary category has experienced a negative per cent fall. The region has also experienced very high magnitude of feminisation-cum-casualisation of employment in the construction sector particularly during the period 2004-05 to 200910. All these indicate a situation of distress push and helplessness for the women workforce. It can also be reasoned out from these developments that although the gender gap in the region in non-farm employment space has almost disappeared, the gender deprivation is very much present and disquieting. This gender deprivation is reflected when women workers are increasingly pushed to undertake supportive, residual, casual and non-remunerative works visà-vis men workforce in the region. Hence, there is an urgent need to improve the quality and productivity of women's employment in the region through measures of intervention and inducement.

In 2009-10, a great transformation-cumconvergence happened with respect to NER and the country in RNFE space. The construction sector emerged as the leading sector of employment with more or less similar share (approximately 30 per cent) in RNFE category both at the level of NER and the country. The inference of such an obvious development leading to convergence in construction sector employment may be because of a continuous fall in public employment in NER because of the restructuring of public salaried/regular employment provisions and decline in manufacturing employment at national level because of technology-enabled manufacturing growth in large scale industries. Even with diminishing manufacturing employment at the level of the country, its share in RNFE in 2009-10 
remains twice of such share for the NER. In fact NER's share of manufacturing employment in RNFE category has undergone a gradual decline during the whole period of 1993-94 to 2009-10. The other sector in RNFE category where there is more or less a convergence of employment share both in the NER and the country is trade, hotel and restaurant. The area where the NER strikes a difference from the country is in the public services sector. In 2009-10, the share of this sector in RNFE category in NER constitutes 27.1 per cent as against all India share of 14.9 percent suggesting thereby that the dominance of the government as provider of employment in RNFE domain although has relatively decreased, still continues to be critical. This assumes further credence with the otherimportant revelation that much of the employment creation in construction sector could be due to employment in public works programmes like MGNREGA. What finally we deduce from these developments is that RNFE in NER as a whole is yet to emerge as an autonomous productive form of employment, with of course, exceptions of employment in sectors like trade, hotel and restaurant. This finding makes it imperative to create more of induced quality employment in the manufacturing and high-end services sectors.

A process analysis of structural transformation of rural employment in NER explains that participation of the households in non-farm activity is significantly influenced by both development as well as distress factors. The important developmental factors are household income from agriculture, access to credit and distance from nearest urban centre. Increased income from agriculture (agricultural growth) has positively influenced the growth of RNFE primarily through consumption linkages. Agricultural growth-led production linkage diversification seems to be weak. Poverty of households has emerged as one of the important distress factors pushing households to opt for non-farm activities as a strategy of survival. Hence, the structural transformation of rural employment scenario in the NER confirms to both J ohn Mellore's farm and non-farm linkage hypothesis and Vaidyanthan's residual sector hypothesis. Therefore, to make the process of diversification of employment more efficient and productive, there is an urgent need to strengthen the production linkage aspect of agricultural growth through inter-sectoral production linkages. Further, agricultural productivity needs to be increased through crop diversification and commercialisation. Access to credit particularly to the poor is limited. It needs to be scaled up to see its increased impact on quality diversification of non-farm employment. The rural and urban areas need to be connected in terms of better road, finance and marketing arrangements for realisation of improved and productive non-farm employment diversification. In the end, the NER's political economy is going to experience structural changes in the form of withdrawal of the State from some of its present myriad horizontal activities as a part of the overall national mandate of minimum government and maximum governance. Given the present arrangement of pervasive government in NER, such a structural change in its political economy would have its restraining impact on the size of jobs in the public sector per se. This makes it extremely crucial on the part the Central as well as State governments in the region to prepare immediate action plans in the light of some of the above findings to make the rural structural diversification process of non-farm employment generation efficient and productive. 


\section{References}

1. Chadha, G K (1993), “Non-Farm Employment for Rural Households: Evidence and Prognosis,"Indian Journal of Labour Economics, Vol 38, No. 3, pp. 296-327.

2. Chenery, HB (1960), "Patterns of Industrial Growth,"American Economic Review, Vol 50, No. 4, pp. 624 654.

3. Clark, Colin (1940), "Conditions of Economic Progress," London: Macmillan \& Co Ltd.

4. Dirven, Martine (2011): "Non-farm Rural Employment and Rural Poverty Reduction:What We know in Latin America in 2010,"Paper Presented at the IFAD Conference on New Directions for Smallholder Agriculture, Rome, Italy, 24-25, J anuary 2011, available at http://www.ifad.org/events/agriculture/ doc/papers/dirven.pdf, accessed on 11 September 2015.

5. Fisher, AGB (1939), "Production: Primary, Secondary and Tertiary,”Economic Record, Vol 15, No. 1, pp. 24-38.

6. Hazell and Haggblade (1991), "Rural-Urban Growth Linkages in India," Indian Journal of Agricultural Economics, Vol 46, No. 4, pp. 515-529.

7. Hymer, S and SResnick (1969), "A Model of Agrarian Economy with Non-Agricultural Activities," American Economic Review, Vol 59, No.4, pp.493-506.

8. ILO (1984), "Promotion of Employment and Income for Rural Poor Including Rural Women through Non-Farm Activities," International Labour Organisation, Geneva.

9. Jha, Brajesh (2006), "Rural Non-Farm Employment in India: Macro-Trends, Micro-Evidences and Policy Options," Delhi: Agricultural Economics Unit, Institute of Economic Growth.

10. Jonasson, E and Helfand, S (2010), "How Important are Locational Characteristics for Rural Nonagricultural Employment? Lessons from Brazil," World Development, Vol 38, No. 5, pp. 727-741.

11. Kaur, Simrit, V Kulkarni, R Gaiha and M Pandey (2010), "Prospects of Non-Farm Employment and Welfare in Rural Areas," ASARC Working Paper No. 5/2010.

12. Kuznets, S (1966), “Modern Economic Growth:Rate,Structure and Spread,"New Haven:Yale University Press.

13. Lahoti, Rahul and Hema Swaminathan (2013),"Economic Growth and Female Labour Force Participation in India," IIM Bangalore Working Paper No. 414, June.

14. Lewis,WA(1954),"Economic Development with Unlimited Supplies of Labour,"The Manchester School, Vol 22, No. 2, pp. 139-191.

15. Mellor, John W (1976), "The New Economics of Growth: A Strategy for India and the Developing World," London: Cornell University Press.

16. Mishra, Deepak (2007), "Rural Non-Farm Employment in Arunachal Pradesh-Growth, Composition and Determinants," NLI Research Studies Series, No. 075, J une.

17. NSSO (1994), "Reports on Employment and Unemployment, 50"h Round, "Department of Statistics. 
18. - - - (1999), "Reports on Employment and Unemployment, $55^{\text {th }}$ Round, "Department of Statistics.

19. - - - (2005),"Reports on Employment and Unemployment, $61^{\text {st }}$ Round, "Department of Statistics.

20. - - - (2010), "Reports on Employment and Unemployment, $66^{\text {th }}$ Round,"Department of Statistics.

21. Panda, B (1999), 'Growth, Composition and Determinants of Rural Non-Farm Employment in Arunachal Pradesh," The Indian Journal of Labor Economics, Vol 42, No. 2, pp. 283-289.

22. Panda, B (2012), "Growth, Composition and Determinants of Rural Non-Farm Employment in North East India," NLI Research Studies Series, No. 097.

23. Pandey, Aviral and Raman Rakesh (2012), "Rural Non-Farm Economy in India: A Study of Uttar Pradesh," Journal of Community Positive Practices, Issue No. 2, pp. 222-239.

24. Samal, K C (1997), "Features and Determinants of Rural Non-Farm Sector in India and Orissa-A Survey,"Journal of Indian School of Political Economy, Vol 9, No. 1, pp.65-93.

25. Sharad, Ranjan (2009), "Growth of Rural Non-Farm Employment in Uttar Pradesh: Reflections from Recent Data,"Economic \& Political Weekly, Vol 44, No. 04, pp. 63-70.

26. Srivastav, N. and Amaresh Dubey (2002), "Rural Non-farm Employment in India: Spatial Variations and Temporal Change", Indian Journal of Labour Economics, Vol 45, No.1, pp. 745-758.

27. Unni,J (1991), “Regional Variation in Rural Non-Agricultural Employment: An Exploratory Analysis,” Economic Political Weekly, Vol 26, No.3, pp. 109-122.

28. Vaidyanathan, A., (1986), "Labour Use in Rural India: A Study of Spatial and Temporal Variation," Economic and Political Weekly,Vol.21,No. 52, pp.A 130-146.

29. Verma, Binoy N and Verma Neelam (1995), "Distress Diversification from Farm to Non-Farm Employment Sector in the Eastern Region" Indian Journal of Agricultural Economics, Vol 50, No. 3, pp. 422-29.

30. World Bank (1978), "Rural Enterprise and Non-Farm Employment," Washington DC.

31. World Bank (1996), "Ecuador Poverty Report," World Bank Country Study, Washington DC. 